\title{
Probiotics in Psychosocial Stress and Anxiety. A Systematic Review
}

\author{
Paola Vitellio ${ }^{1,2,3}$, Alexandra Chira ${ }^{3}$, Maria De Angelis ${ }^{1}$, Dan L. Dumitrascu ${ }^{3}$, Piero Portincasa ${ }^{1}$
}

\author{
1) A Murri Clinica Medica, \\ Department of Biomedical \\ Sciences and Human \\ Oncology, University of Bari \\ Aldo Moro, Italy \\ 2) Department of Soil, Plant \\ and Food Sciences, University \\ of Bari Aldo Moro, Italy \\ 3) $2^{\text {nd }}$ Medical Department, \\ Emergency Clinic County \\ Hospital, Iuliu Hatieganu \\ University of Medicine and \\ Pharmacy, Cluj-Napoca, \\ Romania
}

\author{
Address for correspondence: \\ Prof Dan L Dumitrascu \\ $2^{\text {nd }}$ Medical Department, \\ Emergency Clinic County \\ Hospital, \\ Iuliu Hatieganu University of \\ Medicine and Pharmacy, Cluj- \\ Napoca, Romania \\ ddumitrascu@umfcluj.ro
}

Received: 13.08 .2019

Accepted: 05.02.2020

\begin{abstract}
Background \& Aims: Recent mounting evidence suggest that probiotics supplementation can have a positive effect on mood and psychological symptoms such as stress and anxiety disorders. The majority of studies, however, rely on animal models, while clinical data are still inconsistent. In this systematic review, we examined if and to which extent probiotics can influence psychological stress and anxiety disorders.

Methods: The search of online databases Medline, PubMed, Scopus, Web of Science and clinical trials.gov provided relevant studies up to November 2019. We included double blind, randomized and placebo controlled or prospective studies, as well as studies measuring preclinical psychological symptoms of perceived stress and anxiety, before and after supplementation with a probiotic.

Results: Twelve studies met the inclusion criteria ( 3 on stress, 4 on anxiety, and 5 both on stress and anxiety), accounting for 1,521 participants. The improvement of stress, anxiety, and stress-anxiety was reported in 1/3, $3 / 4$, and $2 / 5$ studies, respectively.

Conclusions: Available studies suggest that probiotics may improve psychological symptoms associated particularly with anxiety. Further research needs to investigate whether probiotics also improve psychological stress disturbances.
\end{abstract}

Key words: microbiota - probiotics - IBS - anxiety - stress.

Abbreviations: B.: Bifidobacterium; CFS: Chronic fatigue syndrome; CFU: Colony-Forming Units; DASS: Depression Anxiety and Stress Scale; GHQ: General Heath Questionnaire; HAD: Hospital Anxiety and Depression Scale; HAMA: Hamilton Anxiety Rating Scale; IBS: irritable bowel syndrome; L.: Lactobacillus; Lc: Lactococcus; SCFAs: short chain fatty acids; SI: symptom intensity; St.: Streptococcus; STAI: State Trait Anxiety Inventory; VAS: Visual Analogical Scale.

\section{INTRODUCTION}

Psychological stress and anxiety are the most common causes of mental health disorders, mainly in developed countries [1]. Stress is a feeling of strain and pressure and according to the duration, psychological stress can be either acute or chronic [2]. On the other hand, pervasive worry, fear, and alterations of behaviour characterize anxiety disorders, interfering with normal routine and the quality of life [3]. With the progress of studies in brain and mental disorders, the role of the interplay between gut microbiota, metabolic pathways with respect to mental disturbance, has emerged [4]. Gut microbes and related metabolites communicate with the brain through the vagus nerve and therefore can have an impact on the central neurochemistry [5]. Alteration in the composition of gut microbiota might be involved in stress-related response [6], and chronic fatigue in irritable bowel syndrome (IBS) [7]. Thus, probiotics can represent game changers also in mental disorders treatment [8].

Probiotics are microorganisms that positively supplement the gut providing beneficial effects [9]. Gastrointestinal symptoms such as constipation, diarrhoea, and abdominal pain are frequent in many mental diseases. This aspect points to the importance of maintaining a balanced connection between gut and brain [10]. The effects through which probiotics may influence the brain are various. Firstly, it is remarkable that specific probiotics modulate intestinal permeability, mitigate stress-induced glucocorticoids and/ 
or inflammatory cytokine responses in association with a reduction of depression and anxiety-related behaviour $[11,12]$. Secondly, probiotics influence microbial-derived metabolites, including short chain fatty acids (SCFAs). In particular, dietary carbohydrates (e.g., resistant starches and soluble dietary fibers) act as substrates for intestinal fermentation, and result in SCFAs (e.g., acetate, propionate, and butyrate). Both the species and quantity of colonic microbiota govern the rate and amount of SCFAs production. In addition, the type of carbohydrate and gut transit time influence the characteristics of SCFAs. In general, butyrate provides the major energy source for colonocytes, the liver mainly takes up propionate, while acetate enters the peripheral circulation and is metabolized by peripheral tissues. Thus, SCFAs have a large number of physiologic effects, including cell signalling pathways, anti-inflammatory properties, and a positive modulation of gene expression [13].

In principle, probiotics can have several beneficial effects on mental disorders and related gastrointestinal symptoms, but their action is still under debate [14]. A number of experimental approaches in animal models investigated the modulatory effect of probiotics on gut-brain interactions. Protocols looked at the effects of microbial manipulations by antibiotics and faecal transplantation in mice under stressconditions [15]. In germ-free mice, studies found a correlation between intestinal dysbiosis and anxiety related behaviour, with increased exploration of aversive zones and improved serotoninergic function [16].

Despite the growing interest of research in this field, the literature is lacking regarding the role of probiotics in psychological stress and anxiety in humans. Here, we designed a systematic review to evaluate the data concerning the effectiveness of probiotics in human mood disorders. The paper focuses on the outcome of the treatment with the most trialled probiotics.

\section{METHODS}

\section{Searching strategy}

The systematic search concerned the following databases: Medline, PubMed, Scopus, Web of Science and clinical trials.gov. Search terms included "bacteria", "cultured," and "probiotics", along with "anxiety", "stress". Therefore, all relevant articles written in English, from January 1991 to November 2019 were included. The reference lists of identified articles were carefully searched for additional information.

\section{Study selection}

The selection included double blind, prospective, randomized and placebo-controlled studies. No constraint existed on dosage, strain, or form/pharmacological conditioning of probiotics. No exclusion criteria regarding gender existed. Exclusion criteria included: animal studies; research studies dealing only with major depression; children (mean age $\leq 16$ years), or older adults (mean age $65 \geq$ years); pregnant women; probiotics not living at time of administration (e.g. heat killed); triple blind, single arm and open label trials; absence of a scale for the measurement of anxiety and stress; studies reporting no or inconsistent results.
The PRISMA process allowed the study selection (preferred reporting items for systematic reviews and meta-analyses).

\section{Dimensions of psychological symptoms}

We analysed the main scales for stress and anxiety (eventually accompanied by depression) in the selected studies.

Psychological stress was defined as a perceived feeling of irritability and tension, which interfered with normal daily routine and sleep quality [14, 17-23]. Authors used different scales to quantify psychological stress. Tools included the general scale for pain or discomfort, i.e., the $10-\mathrm{cm}$ Visual Analogue Scale (VAS with $0=$ "no stress" and $10=$ "extreme stress") [17, 22]. Another study used an indirect method for psychological stress measurement (i.e., State Trait Anxiety Inventory= STAI) [19].

Studies evaluated psychological stress and anxiety by Depression Anxiety and Stress Scale (DASS) [14, 21]. Other authors used combined scales, i.e., General Health Questionnaire (GHQ) (indirect measure of psychological stress) associated with STAI (for anxiety) [18]. Anxiety and stress were also assessed by the Hospital Anxiety and Depression Scale (HAD) associated with STAI [20] or the Hamilton Anxiety Rating Scale (HAMA) associated with DASS [23]. Anxiety alone was assessed by $\operatorname{HAD}[24,25,26]$ or HAMA [23].

\section{Outcome}

The primary outcome was the psychological effects of probiotics in anxiety or psychological stress using at least one scale for the evaluation of symptoms. The secondary outcome was the determination of the most studied probiotic mixtures.

\section{Data extraction and risk of bias}

Only studies with results were included in the analysis. The following data were extracted from each study: authors and year, sample size and characteristics, study design, duration, strains and cell density (expressed in CFU, Colony-Forming Units), modality of assumptions of probiotics, measurements and outcome/findings. The title and abstract for each search result were screened by two independent reviewers (PV) and (AC). They independently applied the inclusion/ exclusion criteria to the study. In cases of a non-consensus, an independent party DLD, PP took the decision.

\section{RESULTS}

The flow-chart of the systematic literature search and selection process is depicted in Fig 1 . We initially found 1,555 records. After screening, the final group consisted of 12 records accounting for 1,521 participants. All studies passed the quality assessment at $>50 \%$ (data not shown). The characteristics of the included studies appear in Table I. The years of publication ranged from 2004 to 2018 . Three papers, out of the 12 selected studies $[18,19,23]$ were based on prospective randomized, placebo-controlled studies with parallel groups, meanwhile the others were randomized, double blind placebo-controlled studies. In the study of Marcos et al. (2004) [19], no information existed regarding gender. 


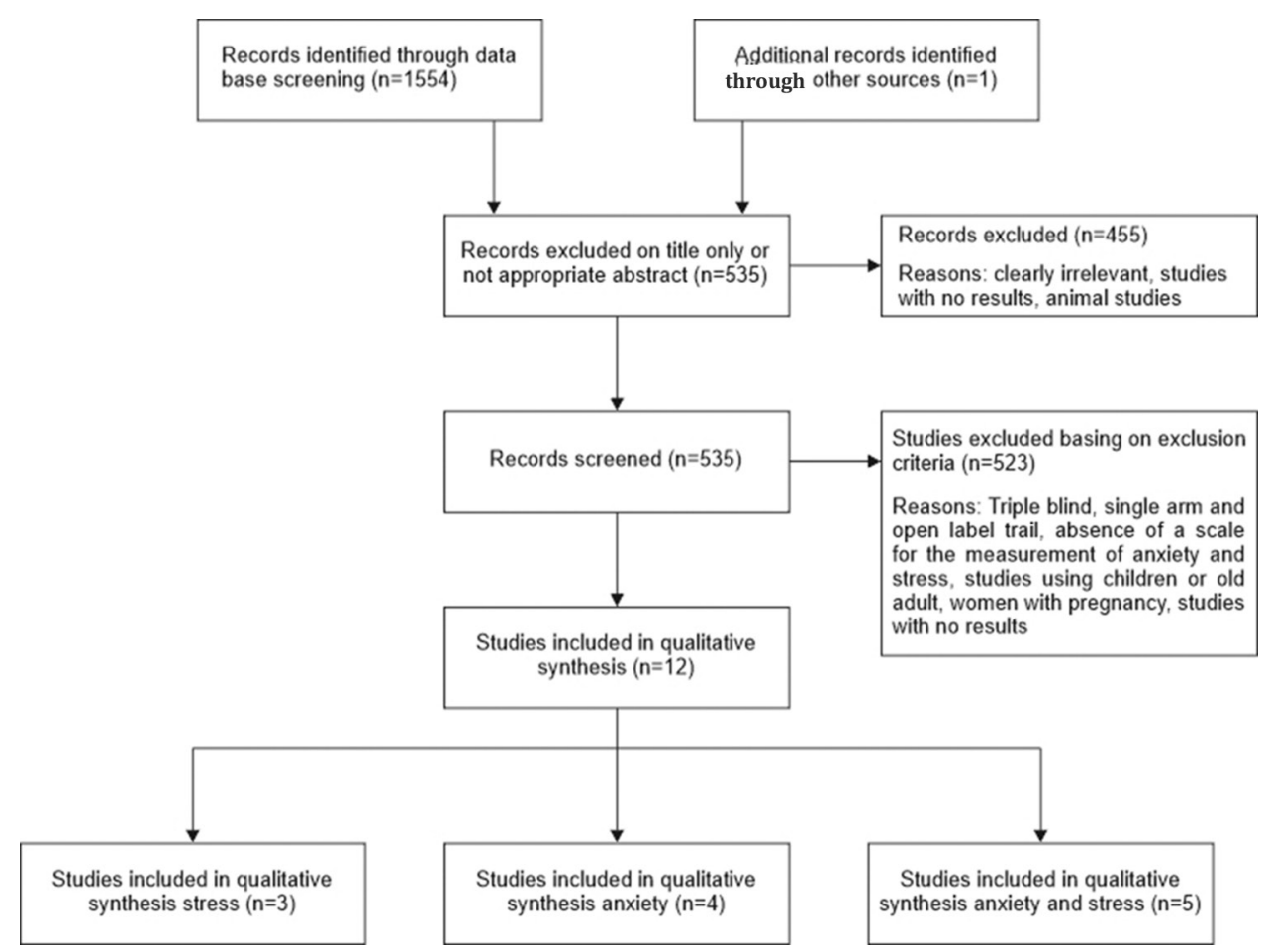

Fig. 1. Flow chart of the systematic literature search and selection process using preferred reporting items for systematic reviews and meta-analyses (PRISMA) process.

All selected studies assessed commensal bacterial species. All formulations contained lactobacilli and/or bifidobacteria but also Streptococcus [19,23] and Lactococcus [24]. No other bacterial species were trialled in the included studies. Four studies [24-27] used one probiotic strain and the other seven studies described a mixture of strains.

Lactobacillus (L.) casei was trialled in 5 out of the 12 selected studies, but no improvement of psychological stress was reported [20,27], while an improvement of anxiety was reported [21, 25]. The studies of Kato-Kataoka et al. [20], and Takada et al. [18] used L. casei (strain 9029) with a cell density of $1.0 \times 10^{9} \mathrm{CFU} / \mathrm{ml}$ in milk ( $100 \mathrm{ml}$ milk daily, thus $1.0 \mathrm{X} 10^{11}$ ). Meanwhile, in the study of Rao et al. [25], the same strain was given as sachets at higher cell-density $\left(2.40 \times 10^{10} \mathrm{CFU} / \mathrm{g}\right.$ daily sachet). A different strain of $L$. casei (DN-114001) at different cell-density $\left(1 \times 10^{8} \mathrm{CFU} / \mathrm{ml}\right.$ daily $)$ was also trialled in the mixture of strains in the study of Marcos et al. (2004) [19] and in the work of Mohammadi et al. [21] at cell-density of $1 \times 10^{7} \mathrm{CFU} / \mathrm{g}$ (100 g/daily, thus $\left.1 \times 10^{9}\right)$. Bifidobacterium (B.) longum was also tested in 5 out the 12 selected studies. Improvement of symptoms was reported in all studies except in the work of Diop et al. [22] valuating psychological stress and in the one of Romjin et al. [14] valuating both stress and anxiety. In particular B. longum was contained in the probiotic formulations at cell-density of $3 \times 10^{9} \mathrm{CFU} / \mathrm{g}$ in the studies of Diop et al. [22], Lamgkamp-Henken et al. [17], and Colica et al. [27]. Mohammadi et al. (2015) [21] trialled B. longum at cell-density of $1 \times 10^{7} \mathrm{CFU} / \mathrm{g}$, meanwhile in the work of Romjin et al. [14], B. longum NCC3001 was tested as a single strain probiotic at cell-density of $1 \times 10^{10} \mathrm{CFU} / \mathrm{g}$. No studies, except the one of Simren et al. [28], among those included in our systematic review, reported information on the composition of diet during the study period (e.g. percentage of proteins) or reported a supplementation of daily diet with fibres.

\section{Psychological stress}

Three studies were included in our analysis accounting for 785 subjects $[17,19,22]$. All subjects were healthy. Two studies used the VAS scale to monitor the stress $[17,22]$. The followup of the studies with stress ranged from 6 to 11 weeks. In the work of Marcos et al. [19], L. casei was contained in the trial in the multiple strains formulation, but no improvement of stress was reported. The only study reporting an improvement of psychological stress was the one of Langkamp- Henken et al. [17] (B. bifidum R0071, B. longum ssp. infantis R0033 and L. helveticus R0052) meanwhile in that of Diop et al. [22] (L. acidophilus Rosell-52 and B. longum Rosell-175), the improvement existed for stress-related abdominal pain $(\mathrm{p}=0.04)$ but not for psychological disturbance.

\section{Anxiety}

Four studies reported on the effect of probiotics in anxiety, with a total sample of 335 subjects [24-28]. IBS was reported in 218 out of the 335 subjects $(65.07 \%)$. The length of the followups ranged from 3 weeks to 2 months. All studies reported an improvement of anxiety, except the one by Pinto-Sanchez et al. [24], which reported an improvement of the total HAD score, with an amelioration of the depression score but not that of anxiety (Table I). In the study of Colica et al. [27], the improvement of anxiety occurred within 3 weeks. This study was the only one, among those considering anxiety, that trialled multiple strain probiotics.

\section{Psychological stress and anxiety}

Five out of the 12 identified studies examined both psychological stress and anxiety, with 400 subjects included in the analysis with a follow-up ranging from 6 to 12 weeks [14, 18, 20, $21,23]$. Only one study considered patients with moderate mood alteration (moderate score in DASS questionnaires) [14]. Takada 
Table I. Characteristics of the selected studies

\begin{tabular}{|c|c|c|c|c|c|c|c|}
\hline $\begin{array}{l}\text { Authors and } \\
\text { year }\end{array}$ & $\begin{array}{l}\text { Sample } \\
\text { size and } \\
\text { characteristics }\end{array}$ & Study design & Duration & $\begin{array}{l}\text { Strains and cell-density } \\
\text { (Colony-Forming Units, } \\
\text { CFU) }\end{array}$ & $\begin{array}{l}\text { Modality of } \\
\text { administration }\end{array}$ & $\begin{array}{l}\text { Psychological } \\
\text { symptom / } \\
\text { Scale }\end{array}$ & $\begin{array}{l}\text { Outcome/key } \\
\text { findings }\end{array}$ \\
\hline $\begin{array}{l}\text { Marcos et al., } \\
2004 \text { [19] }\end{array}$ & $\begin{array}{l}155 \text { Healthy } \\
\text { students aged } \\
18-23 \text { years } \\
\text { old }\end{array}$ & $\begin{array}{l}\text { Prospective, } \\
\text { randomized, } \\
\text { placebo controlled } \\
\text { and parallel study }\end{array}$ & 6 weeks & $\begin{array}{l}1 \times 10^{7} \text { CFU/ml of } L \text {. } \\
\text { delbrueckii subsp. } \\
\text { bulgaricus, St. salivarius } \\
\text { subsp. thermophilus }\left(1 \times 10^{8}\right. \\
/ \mathrm{ml}), \text { L. casei DN114001 } \\
\left(1 \times 10^{8} / \mathrm{ml}\right)\end{array}$ & Milk & Stress / STAI & Unchanged \\
\hline $\begin{array}{l}\text { Diop et al., } \\
2008[22]\end{array}$ & $\begin{array}{l}37 \text { Healthy } \\
\text { volunteers } 18- \\
60 \text { years old }\end{array}$ & $\begin{array}{l}\text { Randomized } \\
\text { double blind } \\
\text { placebo-controlled } \\
\text { study }\end{array}$ & 3 weeks & $\begin{array}{l}3 \times 10^{9} \mathrm{CFU} / \mathrm{g} \text { of } L \text {. } \\
\text { acidophilus Rosell-52 and } \\
\text { B. longum Rosell-175 (all } \\
\text { same cell-density) }\end{array}$ & Sachets & $\begin{array}{l}\text { Stress / SI } \\
\text { (VAS) }\end{array}$ & Unchanged \\
\hline $\begin{array}{l}\text { Langkamp- } \\
\text { Henken et al., } \\
2015 \text { [17] }\end{array}$ & $\begin{array}{l}583 \text { Healthy } \\
\text { undergraduate } \\
\text { students } \\
\text { average age } 20 \\
\text { years }\end{array}$ & $\begin{array}{l}\text { Randomized } \\
\text { double blind } \\
\text { placebo-controlled } \\
\text { study }\end{array}$ & 6 weeks & $\begin{array}{l}3 \times 10^{9} \text { CFU/g of: B. bifidum } \\
\text { R0071, B. longum ssp. } \\
\text { infantis R0033 and L. } \\
\text { helveticus R0052 (all same } \\
\text { cell-density) }\end{array}$ & Capsule & $\begin{array}{l}\text { Stress / SI } \\
\text { (VAS) }\end{array}$ & Improved \\
\hline $\begin{array}{l}\text { Rao et al., } 2009 \\
{[25]}\end{array}$ & $\begin{array}{l}39 \text { Patients } \\
\text { with CFS aged } \\
18-65 \text { years old }\end{array}$ & $\begin{array}{l}\text { Randomized } \\
\text { double blind } \\
\text { placebo-controlled } \\
\text { study }\end{array}$ & 8 weeks & $\begin{array}{l}2.4 \times 10^{10} \mathrm{CFU} / \mathrm{g} \text { of } L . \text { casei } \\
\text { Shirota } 9029\end{array}$ & Sachet & $\begin{array}{l}\text { Anxiety / } \\
\text { HAD }\end{array}$ & Improved \\
\hline $\begin{array}{l}\text { Simren et al., } \\
2010[28]\end{array}$ & $\begin{array}{l}74 \text { Adults with } \\
\text { IBS; average } \\
\text { age } 44\end{array}$ & $\begin{array}{l}\text { Randomized, } \\
\text { double-blind, } \\
\text { controlled study }\end{array}$ & 8 weeks & $\begin{array}{l}5 \times 10^{7} \mathrm{CFU} / \mathrm{ml} \text { of: } L . \\
\text { paracasei subsp. paracasei } \\
\text { F19, L. acidophilus La5, } \\
\text { and B. lactis Bb12 (all same } \\
\text { cell-density) }\end{array}$ & Milk & $\begin{array}{l}\text { Anxiety / } \\
\text { HAD }\end{array}$ & Improved \\
\hline $\begin{array}{l}\text { Colica et al., } \\
2017 \text { [27] }\end{array}$ & $\begin{array}{l}45 \text { Healthy } \\
\text { volunteers } \\
\text { aged } 20-75 \\
\text { years old }\end{array}$ & $\begin{array}{l}\text { Prospective, } \\
\text { randomized, } \\
\text { placebo controlled } \\
\text { and parallel study }\end{array}$ & 3 weeks & $\begin{array}{l}3 \times 10^{9} \mathrm{CFU} / \mathrm{g} \text { of: } L \text {. } \\
\text { helveticus } \mathrm{R} 0052 \text {, and } B \text {. } \\
\text { longum } \mathrm{R} 0175 \mathrm{CNCM} \\
\text { strain I-3470 (all same cell- } \\
\text { density) }\end{array}$ & Sachets & $\begin{array}{l}\text { Anxiety / } \\
\text { HAMA }\end{array}$ & Improved \\
\hline $\begin{array}{l}\text { Kato-Kataoka } \\
\text { et al., } 2016 \\
{[20]}\end{array}$ & $\begin{array}{l}47 \text { Healthy } \\
4 \text { th-grade } \\
\text { medical } \\
\text { students } \\
\text { average age } 23\end{array}$ & $\begin{array}{l}\text { Randomized, } \\
\text { double-blind, } \\
\text { placebo- } \\
\text { controlled, } \\
\text { parallel-group } \\
\text { trial }\end{array}$ & 8 weeks & $\begin{array}{l}1.0 \times 10^{9} \mathrm{CFU} / \mathrm{ml} \\
\text { L. casei Shirota } 9029\end{array}$ & Milk & $\begin{array}{l}\text { Anxiety / STAI } \\
\text { Stress / HAD }\end{array}$ & $\begin{array}{l}\text { Unchanged } \\
\text { anxiety } \\
\text { Improved stress }\end{array}$ \\
\hline $\begin{array}{l}\text { Mohammadi } \\
\text { et al., } 2016 \\
{[21]}\end{array}$ & $\begin{array}{l}70 \text { Healthy } \\
\text { petrochemical } \\
\text { workers aged } \\
20-60 \text { years } \\
\text { old }\end{array}$ & $\begin{array}{l}\text { Randomized } \\
\text { double blind } \\
\text { placebo-controlled } \\
\text { study }\end{array}$ & 6 weeks & $\begin{array}{l}1 \times 10^{7} \mathrm{CFU} / \mathrm{ml} \text { of: } \mathrm{B} \text {. } \\
\text { lactis } \mathrm{BB} 12, \text { L. casei, L. } \\
\text { acidophilus, L. rhamnosus, } \\
\text { L. bulgaricus, B. breve, } \\
\text { B.longum (all same cell- } \\
\text { density) St. thermophiles } \\
\left(2.9 \times 10^{10}\right)\end{array}$ & Yogurt & $\begin{array}{l}\text { Anxiety and } \\
\text { Stress / DASS }\end{array}$ & Both improved \\
\hline $\begin{array}{l}\text { Pinto Sanchez } \\
\text { et al., } 2017 \\
\text { [24] }\end{array}$ & $\begin{array}{l}\text { I44 IBS } \\
\text { patients } \\
\text { average age } 43 \\
\text { years }\end{array}$ & $\begin{array}{l}\text { Double-blind, } \\
\text { randomized } \\
\text { placebo- } \\
\text { controlled, single- } \\
\text { center pilot study. }\end{array}$ & 6 weeks & $\begin{array}{l}1.5 \times 10^{10} \mathrm{CFU} / \mathrm{g} \text { of: St. } \\
\text { thermophilus, L. bulgaricus; } \\
\text { Lc. lactis, L. acidophilus, } \\
\text { St. thermophiles, L. } \\
\text { plantarum; B. lactis, } \\
\text { L.reuteri (all same cell- } \\
\text { density) }\end{array}$ & Sachets & $\begin{array}{l}\text { Anxiety / } \\
\text { HAD }\end{array}$ & $\begin{array}{l}\text { Unchanged } \\
\text { anxiety } \\
\text { Improved } \\
\text { depression score }\end{array}$ \\
\hline $\begin{array}{l}\text { Romijn et al., } \\
2017 \text { [14] }\end{array}$ & $\begin{array}{l}79 \text { Patients with } \\
\text { moderate self- } \\
\text { reported mood } \\
\text { alteration } \\
\text { average age } 36 \\
\text { years }\end{array}$ & $\begin{array}{l}\text { Randomized } \\
\text { double blind } \\
\text { placebo-controlled } \\
\text { study }\end{array}$ & 8 weeks & $\begin{array}{l}1 \times 10^{10} \mathrm{CFU} / \mathrm{g} \text { of } B . \\
\text { longum } \mathrm{NCC} 3001\end{array}$ & Sachet & $\begin{array}{l}\text { Anxiety and } \\
\text { Stress / DASS }\end{array}$ & Unchanged \\
\hline $\begin{array}{l}\text { Takada et al., } \\
2017[18]\end{array}$ & $\begin{array}{l}94 \text { Healthy } \\
\text { students } \\
\text { average age } 23 \\
\text { years }\end{array}$ & $\begin{array}{l}\text { A double- } \\
\text { blind, placebo- } \\
\text { controlled, } \\
\text { randomized } \\
\text { parallel-group trial }\end{array}$ & 11 weeks & $\begin{array}{l}1.0 \times 10^{9} \mathrm{CFU} / \mathrm{ml} \text { of } L . \\
\text { casei Shirota } 9029\end{array}$ & Milk & $\begin{array}{l}\text { Anxiety / STAI } \\
\text { Stress / GHQ }\end{array}$ & $\begin{array}{l}\text { Unchanged } \\
\text { anxiety } \\
\text { Improved stress- } \\
\text { induced sleep } \\
\text { disturbance }\end{array}$ \\
\hline
\end{tabular}




\begin{tabular}{|c|c|c|c|c|c|c|c|}
\hline \multicolumn{8}{|c|}{ Table I (continued) } \\
\hline $\begin{array}{l}\text { Lew et al., } \\
2018 \text { [23] }\end{array}$ & $\begin{array}{l}110 \text { Healthy } \\
\text { stressed adults, } \\
18-60 \text { years old }\end{array}$ & $\begin{array}{l}\text { Double blind, } \\
\text { randomized, } \\
\text { placebo controlled } \\
\text { study }\end{array}$ & 12 weeks & $\begin{array}{l}1.0 \times 10^{10} \mathrm{CFU} / \mathrm{g} \text { of } L . \\
\text { plantarum } \mathrm{P} 82 \mathrm{~g} / \text { day }\end{array}$ & Sachet & $\begin{array}{l}\text { Anxiety and } \\
\text { Stress / DASS } \\
\text { Anxiety / } \\
\text { HAMA }\end{array}$ & $\begin{array}{l}\text { Improved anxiety } \\
\text { and stress }\end{array}$ \\
\hline
\end{tabular}

Abbreviations: CFU: Colony-Forming Units; L.: Lactobacillus; B.: Bifidobacterium; St.: Streptococcus; Lc.: Lactococcus; STAI: State Trait Anxiety Inventory; SI: symptom intensity; VAS: (Visual Analogical Scale); CFS: Chronic fatigue syndrome; HAD: Hospital Anxiety and Depression Scale; GHQ: General Heath Questionnaire; DASS Depression Anxiety and Stress Scale; HAMA: Hamilton Anxiety Rating Scale.

et al. [18] and Kato-Kataoka et al. [20] used L. casei in healthy medical students with mean age of 23 years. Treatment lasted 8 weeks [18] and 11 weeks [20] with a good safety profile, and no adverse events. In the study of Kato-Kataoka et al. [20] STAI score did not improve but sleep disturbance improved significantly. In addition, the proportion of stressed students decreased.

\section{DISCUSSION}

In this systematic review, we investigated the effects of probiotics on psychological stress and anxiety disorders. According to our inclusion criteria, our analysis is based on 1,521 participants. Lactobacilli and/or bifidobacteria were trialled in all the included studies, suggesting that strains of lactobacilli and bifidobacteria may provide psychological healthy benefits [29] and could be useful in treating physiological disturbances [30]. Anxiety is often associated with major depression, but we decided to exclude major depression forms from this systematic review. In fact, even if probiotic administration has beneficial effects on the Beck Depression Inventory scores on depressive disorders [31], antidepressants represent the gold standard for the treatment of this disease [32]. According to our results, L. casei and B. longum were one of the most studied strains. However, due to the contradictory results, especially those on psychological stress, we cannot draw definitive conclusions about the effectiveness of these two strains. This finding is in accordance with the work of Wallace and Milev [33] who systematically reviewed 10 randomized controlled trials on the effect of probiotic on anxiety, depression and stress. Liu et al. [34], after screening 12 clinical trials on the same topic, concluded that data in the literature are still inconsistent.

We indeed found that data are rather heterogeneous. Firstly, the pooled patients differed in terms of clinical and psychological conditions. For example, we included both the work of Romjin and Rucklidge et al. [14] with patients with psychiatric symptoms, and healthy individuals [23]. Even the inclusion and exclusion criteria differed between these studies. Moreover, supplement administration varied between the included studies in terms of the duration of the treatment, probiotic type and cell-density. However, according to our results, we could assume that the effect of probiotic lactobacilli and bifidobacteria strains in psychological stress seems to be more limited or absent if compared to that on anxiety. Even if evidence exists regarding the contribution of probiotics in improving stress [35], the literature is still very poor in this respect [36]. Moreover, a controlled diet was lacking in any of the selected studies, and all patients followed their normal routine-diet. Thus, since the composition of diet strongly impacts gut microbiota, relative metabolome and mental health
[37], this aspect should also be assessed in further studies in this field.

None of the studies with the exception of Kato-Katoka et al. [20], examined the microbiota at baseline or after treatment. Thus, there is the possibility of dysbiosis in patients considered otherwise healthy. In this case, the improvement of psychological outcome might be secondary to the restoration of gut microbial balance. In particular, the existence of dysbiosis is largely demonstrated in IBS [38, 39, 40], as well as the relationship between mood disorder and IBS onset [41]. Interestingly, both Pinto-Sanchez et al. [24] and Simren et al. [28] included IBS patients, and both studies reported an improved HAD score. Data suggest that probiotics could improve gastrointestinal disturbance and quality of life in IBS patients $[42,43]$, as well as in patients with Chronic Fatigue Syndrome [44].

\section{CONCLUSIONS}

This review indicates that treatment with probiotic lactobacilli and bifidobacteria strains may particularly improve psychological symptoms associated with anxiety. Despite extensive preclinical data, further studies need to determine the ultimate efficacy probiotics in alleviating psychological stressrelated disorders. Moreover, more double-blind randomized controlled trials, and prospective studies need to address additional key points. These include the efficacy of other probiotic formulations in improving psychological outcome, the role of the diet, and the involvement of a possible dysbiosis in the onset of these disorders.

Conflicts of interest: None to declare.

Authors' contributions: D.L.D.: study concept and design; A.C, P.V. literature search and data acquisition; D.L.D., M.D.A., P.P.: data analysis. All the authors were involved in the writing of the manuscript and approved the final version.

\section{REFERENCES}

1. Centers for Disease Control and Prevention. Burden of Mental Illness. Burden of Mental Illness. Mental health. 2013.

2. Abe H, Hidaka N, Kawagoe C, et al. Prenatal psychological stress causes higher emotionality, depression-like behavior, and elevated activity in the hypothalamo-pituitary-adrenal axis. Neurosci Res 2007;59:145-151. doi:10.1016/j.neures.2007.06.1465

3. Surdea-Blaga T, Baban A, Nedelcu L, Dumitrascu DL. Psychological Interventions for Irritable Bowel Syndrome. J Gastrointestin Liver Dis 2016;25:359-366. doi:10.15403/jgld.2014.1121.253.ibs 
4. Gelfuso ÉA, Rosa DS, Fachin AL, Mortari MR, Cunha AO, Beleboni RO. (2014). Anxiety: a systematic review of neurobiology, traditional pharmaceuticals and novel alternatives from medicinal plants. CNS Neurol Disord Drug Targets 2014;13:150-165. doi:10.2174/187152731 13129990102

5. Deding U, Torp-Pedersen C, Bøggild H. Perceived stress as a risk factor for dyspepsia: a register-based cohort study. Eur J Gastroenterol Hepatol 2017;29:560-567. doi:10.1097/meg.0000000000000831

6. Cryan JF, Dinan TG. Mind-altering microorganisms: the impact of the gut microbiota on brain and behaviour. Nat Rev Neurosci 2012;13:701712. doi:10.1038/nrn3346

7. Saulnier DM, Riehle K, Mistretta TA, et al. Gastrointestinal microbiome signatures of pediatric patients with irritable bowel syndrome. Gastroenterology 2011;141:1782-1791. doi:10.1053/j.gastro.2011.06.072

8. De Angelis M, Francavilla R, Piccolo M, De Giacomo A, Gobbetti M. Autism spectrum disorders and intestinal microbiota. Gut Microbes 2015;6:207-213. doi:10.1080/19490976.2015.1035855

9. Hong SN, Rhee PL. Unraveling the ties between irritable bowel syndrome and intestinal microbiota. World J Gastroenterol 2014;20:2470-2481. doi:10.3748/wjg.v20.i10.2470

10. Westfall S, Lomis N, Kahouli I, Dia SY, Singh SP, Prakash S. Microbiome, probiotics and neurodegenerative diseases: deciphering the gut brain axis. Cell Mol Life Sci 2017;74:3769-3787. doi:10.1007/s00018-0172550-9

11. Edogawa S, Edwinson AL, Peters SA, et alSerine proteases as luminal mediators of intestinal barrier dysfunction and symptom severity in IBS. Gut 2020;69:62-73. doi:10.1136/gutjnl-2018-317416

12. Julio-Pieper M, Bravo JA, Aliaga E, Gotteland M. Review article: intestinal barrier dysfunction and central nervous system disorders - a controversial association. Aliment Pharmacol Ther 2014;40:1187-1201. doi:10.1111/apt.12950

13. Cani PD, Everard A, Duparc T. Gut microbiota, enteroendocrine functions and metabolism. Curr Opin Pharmacol 2013;13:935-940. doi:10.1016/j.coph.2013.09.008

14. Romijn AR, Rucklidge JJ, Kuijer RG, Frampton C. A double-blind, randomized, placebo-controlled trial of Lactobacillus helveticus and Bifidobacterium longum for the symptoms of depression. Aust N Z J Psychiatry 2017;51:810-821. doi:10.1177/0004867416686694

15. Desbonnet L, Garrett L, Clarke G, Bienenstock J, Dinan TG. The probiotic Bifidobacteria infantis: an assessment of potential antidepressant properties in the rat. J Psychiatr Res 2008;43:164-174. doi:10.1016/j.jpsychires.2008.03.009

16. Bested AC, Logan AC, Selhub EM. Intestinal microbiota, probiotics and mental health: from Metchnikoff to modern advances: part II - contemporary contextual research. Gut Pathog 2013;5:3. doi:10.1186/1757-4749-5-3

17. Langkamp-Henken B, Rowe CC, Ford AL, et al. Bifidobacterium bifidum R0071 results in a greater proportion of healthy days and a lower percentage of academically stressed students reporting a day of cold/flu: A andomised, double-blind, placebo-controlled study. Br J Nutr 2015;113:426-434. doi:10.1017/S0007114514003997

18. Takada M, Nishida K, Gondo Y, et al. Beneficial effects of Lactobacillus casei strain Shirota on academic stress-induced sleep disturbance in healthy adults: a double-blind, randomised, placebo-controlled trial. Benef Microbes 2017;8:153-162. doi:10.3920/BM2016.0150

19. Marcos A, Wärnberg J, Nova E, et al. The effect of milk fermented by yogurt cultures plus Lactobacillus casei DN-114001 on the immune response of subjects under academic examination stress. Eur J Nutr 2004;43:381-389. doi:10.1007/s00394-004-0517-8
20. Kato-Kataoka A, Nishida K, Takad, M, et al. Fermented milk containing Lactobacillus casei strain Shirota prevents the onset of physical symptoms in medical students under academic examination stress. Benef Microbes 2016;7:153-156. doi:10.3920/BM2015.0100

21. Mohammadi AA, Jazayeri S, Khosravi-Darani K, et al. The effects of probiotics on mental health and hypothalamic-pituitary-adrenal axis: A randomized, double-blind, placebo-controlled trial in petrochemical workers. Nutr Neurosci 2016;19:387-395. doi:10.1179/147683051 5Y.0000000023

22. Diop L, Guillou S, Durand H. Probiotic food supplement reduces stress-induced gastrointestinal symptoms in volunteers: a doubleblind, placebo-controlled, randomized trial. Nutr Res 2008;28:1-5. doi:10.1016/j.nutres.2007.10.001

23. Lew LC, Hor YY, Yusoff NAA, et al. Probiotic Lactobacillus plantarum P8 alleviated stress and anxiety while enhancing memory and cognition in stressed adults: A randomised, double-blind, placebo-controlled study. Clin Nutr 2019;38:2053-2064. doi:10.1016/j.clnu.2018.09.010

24. Pinto-Sanchez MI, Hall GB, Ghajar K, et al. Probiotic Bifidobacterium longum NCC3001 reduces depression scores and alters brain activity: a pilot study in patients with irritable bowel syndrome. Gastroenterology 2017;153:448-459.e8. doi:10.1053/j.gastro.2017.05.003

25. Rao AV, Bested AC, Beaulne TM, et al.A randomized, double-blind, placebo-controlled pilot study of a probiotic in emotional symptoms of chronic fatigue syndrome. Gut Pathog 2009;1:6. doi:10.1186/17574749-1-6

26. Slykerman RF, Hood F, Wickens K, et al. Effect of lactobacillus rhamnosus HN001 in pregnancy on postpartum symptoms of depression and anxiety: a randomised double-blind placebo-controlled trial. EBioMedicine 2017;24:159-165. doi:10.1016/j.ebiom.2017.09.013

27. Colica C, Avolio E, Bollero P, et al. Evidences of a new Psychobiotic formulation on body composition and anxiety. Mediators Inflamm 2017;2017:5650627. doi:10.1155/2017/5650627

28. Simrén M, Ohman L, Olsson J, et al. Clinical trial: the effects of a fermented milk containing three probiotic bacteria in patients with irritable bowel syndrome-a randomized, double-blind, controlled study. Aliment Pharmacol Ther 2010;31:218-227. doi:10.1111/j.13652036.2009.04183.x

29. Bharwani A, Mian MF, Surette MG, Bienenstock J, Forsythe P. Oral treatment with Lactobacillus rhamnosus attenuates behavioural deficits and immune changes in chronic social stress. BMC Med 2017;15:7. doi:10.1186/s12916-016-0771-7

30. Schnorr SL, Bachner HA. Integrative Therapies in Anxiety Treatment with Special Emphasis on the Gut Microbiome. Yale J Biol Med 2016;89:397-422.

31. Akkasheh G, Kashani-Poor Z, Tajabadi-Ebrahimi M, et al. Clinical and metabolic response to probiotic administration in patients with major depressive disorder: A randomized, double-blind, placebo-controlled trial. Nutrition 2016;32:315-320. doi:10.1016/j.nut.2015.09.003

32. Cipriani A, Purgato M, Furukawa TA, et al. Citalopram versus other anti-depressive agents for depression. Cochrane Database Syst Rev 2012;(7):CD006534. doi:10.1002/14651858.CD006534.pub2

33. Wallace CJ, Milev R. The effects of probiotics on depressive symptoms in humans: a systematic review. Ann Gen Psychiatry 2017;16:14. doi:10.1186/s12991-017-0138-2

34. Liu B, He Y, Wang M, et al. Efficacy of probiotics on anxiety-A metaanalysis of randomized controlled trials. Depress Anxiety 2018;35:935945. doi:10.1002/da.22811

35. West NP, Pyne DB, Peake JM, Cripps AW. Probiotics, immunity and exercise: a review. Exerc Immunol Rev 2009;15:107-126. 
36. Brenner LA, Stearns-Yoder KA, Hoffberg AS, et al. Growing literature but limited evidence: A systematic review regarding prebiotic and probiotic interventions for those with traumatic brain injury and/or posttraumatic stress disorder. Brain Behav Immun 2017;65:57-67. doi:10.1016/j.bbi.2017.06.003

37. O’Neil A, Quirk SE, Housden S, et al. Relationship between diet and mental health in children and adolescents: a systematic review. Am J Public Health 2014;104:e31-e42. doi:10.2105/AJPH.2014.302110

38. Collins SM. A role for the gut microbiota in IBS. Nat Rev Gastroenterol Hepatol 2014;11:497-505. doi:10.1038/nrgastro.2014.40

39. Bonfrate L, Tack J, Grattagliano I, Cuomo R, Portincasa P. Microbiota in health and irritable bowel syndrome: current knowledge, perspectives and therapeutic options. Scand J Gastroenterol 2013;48:995-1009. doi $: 10.3109 / 00365521.2013 .799220$

40. Kalani A, Naliboff BD, Shih W, Mayer EA, Chang L. Increased Sleep Disturbances in Irritable Bowel Syndrome (IBS) Patients is Associated with Greater Symptom Severity and Decreased Quality
Of Life. Gastroenterology 2017;152:S716. doi: 10.1016/S0016 5085(17)32491-5

41. Casen C, Vebø HC, Sekelja M, et al. Deviations in human gut microbiota: a novel diagnostic test for determining dysbiosis in patients with IBS or IBD. Aliment Pharmacol Ther 2015;42:71-83. doi:10.1111/apt.13236

42. Portincasa P, Moschetta A, Baldassarre G, Altomare DF, Palasciano G Pan-enteric dysmotility, impaired quality of life and alexithymia in a large group of patients meeting ROME II criteria for irritable bowel syndrome. World J Gastroenterol 2003;9:2293-2299. doi:10.3748/wjg v9.i10.2293

43. Kuijpers PM, Denollet J, Lousberg R, Wellens HJ, Crijns H, Honig A. Validity of the hospital anxiety and depression scale for use with patients with noncardiac chest pain. Psychosomatics 2003;44:329-335. doi:10.1176/appi.psy.44.4.329

44. Logan AC, Rao AV, Irani D. Chronic fatigue syndrome: lactic acid bacteria may be of therapeutic value. Med Hypotheses 2003;60:915-923. doi:10.1016/s0306-9877(03)00096-3 